Agnieszka Watęga*

Toruń

\title{
Obraz edukacji religijnej w Galicji 2. połowy XIX wieku w opinii współpracowników lwowskiej Szkoly
}

\begin{abstract}
Nauka twoja powinna zawsze zmierzać do wykształcenia ducha i serca dzieci. Punktem środkowym jednak powinno być kształcenie dzieci w pobożności i cnocie.

Dzieci przynależą niebu, należy je też wychowywać dla nieba, a wtedy same przez się będą błogosławieństwem ziemi. Wychowanie jest najgłówniejszym zadaniem szkoły ${ }^{1}$.
\end{abstract}

Twórcy koncepcji wychowania narodowego, które w 2. połowie XIX wieku wywarło tak znaczący wpływ na procesy kształcenia i wychowania dzieci i młodzieży na terenach Galicji, przypisywali edukacji religijnej znaczącą rolę. Na ten temat wypowiadali się jej czołowi przedstawiciele, postulując naukę religii w szkołach oraz pracę pedagogów nad rozwijaniem uczuć religijnych uczniów ${ }^{2}$. To w Galicji, co podkreśla Edward Walewander, księża

* Dr hab. Agnieszka Wałęga, prof. UMK jest pracownikiem Katedry Teorii Wychowania na Wydziale Nauk Pedagogicznych UMK w Toruniu. Adres: Wydział Nauk Pedagogicznych UMK, ul. Lwowska 1, 87-100 Toruń; e-mail: awalega@umk.pl.

1 Józef Chmielewski, „Dwanaście artykułów nauczyciela ludowego”, Szkoła 22 (1886): 170.

${ }^{2} \mathrm{Na}$ ten temat szerzej m.in. Joanna Falkowska, „Pierwiastek religijny w wychowaniu narodowym. Postulaty okresu autonomii galicyjskiej”, Paedagogia Christiana 2/30 (2012): 29-45; Joanna Falkowska, Myśl wychowania narodowego w Galicji okresu autonomii. Twórcy i idee (Toruń: Wydawnictwo Adam Marszałek, 2013), 217-222. 
mieli największe możliwości pozytywnego oddziaływania na uczniów, nauczycieli i atmosferę wychowawczą samej szkoły ${ }^{3}$. Także analiza literatury pamiętnikarskiej i wspomnieniowej wychowanków szkół galicyjskich wyraźnie świadczy o tym, że ich nauczyciele prezentowali właściwe postawy i aktywnie uczestniczyli w praktykach religijnych swoich uczniów ${ }^{4}$. Szczególne znaczenie przypisywano w tym zakresie szkole ludowej, to na tym najniższym szczeblu edukacji starano się przede wszystkim realizować zasady edukacji religijnej, miały one stanowić stabilny fundament moralnego życia zwłaszcza dla osób, które nie podejmowały dalszej edukacjis.

U progu autonomii w 1869 roku w Galicji 46,08\% ludności stanowili mieszkańcy wyznania rzymskokatolickiego, 42,53\% deklarowało grekokatolicyzm, a $10,58 \%$ było Izraelitami (przeważali chasydzi). Stan ten utrzymywał się z niewielkimi zmianami do początku XX wieku ${ }^{6}$. Podziały wyznaniowe odzwierciedlały także różnice narodowościowe, Polacy reprezentowali głównie wyznanie rzymskokatolickie, Ukraińcy grekokatolickie, Żydzi deklarowali narodowość polską lub niemiecką, a ewangelicy niemiecką ${ }^{7}$ Poszczególne wyznania miały zagwarantowane prawo do odrębnej edukacji religijnej dzieci w szkołach zgodnie z zapisami Ustawy z dnia 25 maja 1868 roku regulującej stosunki państwo-Kościół na terenie Galicji ${ }^{8}$.

${ }^{3}$ Edward Walewander, Wychowanie chrześcijańskie w nauczaniu i praktyce Kościoła katolickiego na ziemiach polskich w II połowie XIX wieku (Lublin: Towarzystwo Naukowe KUL, 1996), 98.

${ }^{4}$ Por. m.in. Roman Pelczar, „Miejsce wiejskich szkół elementarnych i ich nauczycieli w życiu społeczności chłopskich w Galicji”, Galicja. Studia i materiały 1 (2015): 119, 123-124; Dorota Grabowska-Pieńkosz, Zapisani w pamięci. Nauczyciele zaboru austriackiego w literaturze pamiętnikarskiej (Toruń: Wydawnictwo Naukowe Uniwersytetu Mikołaja Kopernika, 2016), 169-180.

${ }^{5} \mathrm{Na}$ ten temat szerzej m.in. Czesław Majorek, „Urzędowa koncepcja ideału nauczyciela szkoły ludowej w Galicji doby autonomicznej”, Rocznik Komisji Nauk Pedagogicznych X (1970): 207-222.

${ }^{6}$ Beata Hołub, ,Studium historyczno-geograficzne narodowości w Galicji Wschodniej w świetle spisów ludności w latach 1890-1910", Annales Universitatis Mariae Curie-Skłodowska, sectio B: Geographia, Geologia, Minerologia et Petrographia LXVIII/2 (2013): 25-27.

${ }^{7}$ Barbara Łuczyńska, „Udział Towarzystwa Nauczycieli Szkół Wyższych w integrowaniu nauczycieli szkół średnich Galicji 1884-1909”, w: Galicja i jej dziedzictwo, t. 3: Nauka i oświata, red. Andrzej Meissner, Jerzy Wyrozumski (Rzeszów: Wydawnictwo WSP, 1995), $255-256$.

8 Jej § 2 stwierdzał, że „(...) pozostawia się opiekę, kierownictwo i bezpośredni nadzór nad nauką religii i religijnymi ćwiczeniami dla różnych wyznawców w szkołach ludowych i średnich odnośnemu Kościołowi lub religijnemu stowarzyszeniu”. Patrz: „Ustawa z dnia 
Było to istotne, albowiem od schyłku XVIII wieku, gdy rozpoczęto zabiegi o rozwój tamtejszych szkół ludowych, stanowiły one placówki wspólne dla dzieci różnych wyznań i narodowości ${ }^{9}$. Jednak w Radzie Szkolnej Krajowej swoich reprezentantów miał jedynie Kościół katolicki, starań Żydów o osobnego reprezentanta nie uwzględniono ${ }^{10}$. Akty normatywne regulujące stosunki prawne nauczycieli publicznych szkół ludowych wyraźnie stawiały wymóg religijności oraz wyznania adekwatnego do tego, które reprezentowali uczniowie ${ }^{11}$.

Gdy w 1868 roku nauczyciele galicyjscy uzyskali cenną możliwość wymiany swoich doświadczeń zawodowych oraz dokształcania, to wówczas z inicjatywy środowisk pedagogicznych powołano najpierw Towarzystwo Pedagogiczne, a następnie związany z nim periodyk Szkoła. Pismo poświęcone sprawom szkół ludowych i średnich tudzież seminariów nauczycielskich, $\mathrm{z}$ czasem całkowicie dedykowane nauczycielom ludowym ${ }^{12}$. Wśród wielu

25 maja 1868 r. mocą której wydaje się zasadnicze ustanowienia względem stosunku szkoły do kościoła”, Szkoła II/7 (1868): 61.

9 Marianna Krupa, „Szkoła ludowa w Galicji w latach 1772-1790”, Rozprawy z Dziejów Oświaty 24 (1981): 79.

${ }^{10}$ Renata Dutkowa, „Polityka szkolna w Galicji 1866-1890”, w: Galicja i jej dziedzictwo, t. 3, 142-143.

11 Majorek, „Urzędowa koncepcja”, 212-213.

12 Informacje na temat powstania i rozwoju tego pisma odnaleźć można m.in. w następujących publikacjach: Stanisław Zarański, Ocenienie „, Szkoły” pisma poświęconego sprawom szkół ludowych i średnich tudzież seminariów nauczycielskich (Kraków: Drukarnia pisma Czas, 1868); Szkoła 1 (1892) (numer jubileuszowy dotyczący historii czasopisma); Bolesław Adam Baranowski, „Sprawozdanie Bolesława Adama Baranowskiego odczytane na posiedzeniu Zjazdu Towarzystwa Pedagogicznego dnia 27 sierpnia 1908 r. pt. Czterdziestolecie Towarzystwa Pedagogicznego", w: Księga Jubileuszowa Polskiego Towarzystwa Pedagogicznego 1868-1908 (Lwów: Polskie Towarzystwo Pedagogiczne, 1908), 3-4; Antoni Karbowiak, Polskie czasopisma pedagogiczne (Warszawa: Kasa im. Mianowskiego, 1912); Wanda Bobrowska-Nowak, „Problemy pedagogiczne na łamach «Szkoły» w latach siedemdziesiątych ubiegłego stulecia”, Przeglad Historyczno-Oświatowy 2 (1971): 261-277; Czesław Majorek, „Towarzystwo Pedagogiczne i «Szkoła» wobec projektów reform kształcenia nauczycieli ludowych w Galicji z lat 1868-1869", Rocznik Naukowo-Dydaktyczny WSP w Krakowie 43/5 (1972): 289-300; Agnieszka Stopińska-Pająk, „Wkład czasopisma «Szkoła» w rozwój myśli pedagogicznej”, w: Galicja i jej dziedzictwo, t. 8: Myśl edukacyjna w Galicji, 1772-1918, red. Czesław Majorek, Andrzej Meissner (Rzeszów: Wyższa Szkoła Pedagogiczna, 1997), 169-179; Jan Wnęk, „Problemy polskiego szkolnictwa zaboru pruskiego i rosyjskiego na kartach «Szkoły» 1868-1914”, Biuletyn Historii Wychowania 24 (2008): 23-46; Adam Świątek, „Problem patriotycznego wychowania ludu na łamach lwowskiej «Szkoły» w czasach autonomii galicyjskiej”, w: Czasopiśmiennictwo XIX i początków XX wieku jako źródło do historii edukacji, red. Iwonna 
podejmowanych na jego łamach problemów pojawia się także temat edukacji religijnej. Pismo to stanowi cenne źródło dla badaczy poszukujących odpowiedzi na pytanie, w jaki sposób nauczyciele szkół ludowych i seminariów nauczycielskich postrzegali problemy kształtowania uczuć religijnych swoich wychowanków, jaką rolę w tym zakresie przypisywali Kościołowi, szkole, rodzicom i wreszcie samym sobie. Analiza zamieszczonych na jego łamach tekstów pozwala udzielić wyczerpujących odpowiedzi na powyższe pytania, a tym samym nakreślić obraz ówczesnej edukacji religijnej - od zgłaszanych $\mathrm{w}$ tym zakresie postulatów po ich praktyczną realizację $\mathrm{w}$ procesach wychowania i nauczania.

Michalska, Grzegorz Michalski (Łódź: Uniwersytet Łódzki, 2010), 169-184; Adam Świątek, „«Poległ wśród boju nauczycielskiego». Wspomnienia pośmiertne na łamach czasopisma «Szkoła» jako źródło do historii nauczycielstwa galicyjskiego", w: Addenda do dziejów oświaty. $Z$ badań nad prasa XIX i początków XX wieku, red. Iwonna Michalska, Grzegorz Michalski (Łódź: Uniwersytet Łódzki, 2013), 119-130; Agnieszka Wałęga, „Galicyjska «Szkoła» jako przykład czasopisma pedagogicznego okresu zaborów”, Acta Universitatis Nicolai Copernici-Pedagogika XXIX (2013): 9-28; Agnieszka Wałęga, „«Szkoła» najstarsze galicyjskie czasopismo pedagogiczne wobec myśli pedagogicznej pozytywizmu warszawskiego”, w: W stulecie śmierci Jana Władysława Dawida, red. Hanna Markiewiczowa (Warszawa: Akademia Pedagogiki Specjalnej, 2014), 110-119; Agnieszka Wałęga, „O zadaniach wychowawczych rodziny. Koncepcje współpracowników czasopisma «Szkoła»", Wychowanie w rodzinie X/2 (2014): 137-158; Agnieszka Wałęga, „Die deutsche Pädagogik in der Zeitschrift «Szkoła». Ein Beitrag zur Rezeptionsgeschichte im 19. Jahrhundert“, Studienreihe der Polnischen Historischen Mission. Leben zwischen und mit den Kulturen. Studien zu Recht, Bildung und Herrschaft in Mitteleuropa 2 (2015): 131-147; Agnieszka Wałęga, „Nauczyciele galicyjscy w świetle «Szkoły»”, w: Badania biograficzne w pedagogice. Studia źródłowe i bibliograficzne, red. Władysława Szulakiewicz (Torun: Wydawnictwo Naukowe Uniwersytetu Mikołaja Kopernika, 2015), 199-211; Agnieszka Wałęga, „«Z zaborów...». Galicyjska «Szkoła» wobec problemów rozwoju oświaty w Królestwie Polskim (1905-1918), w: Szkolnictwo, opieka i wychowanie w Królestwie Polskim. Od jego ustanowienia do odzyskania przez Polskę niepodległości 1815-1918, red. Hanna Markiewiczowa, Iwona Czarnecka (Warszawa: Akademia Pedagogiki Specjalnej, 2016), 80-89; Agnieszka Wałęga, „ «Szkoła» źródłem w badaniach historyczno-pedagogicznych polskich instytucji edukacyjnych doby zaborów", Studia Paedagogica Ignatiana 19/2 (2016): 253-270; Agnieszka Wałęga, „Dziedzictwo polskiej teorii i praktyki pedagogicznej na kartach «Szkoły»", w: Polskie dziedzictwo pedagogiczne - idee i instytucje, red. Joanna Falkowska (Toruń: Wydawnictwo Naukowe UMK, 2016), 59-75; Agnieszka Wałęga, „Rodziny polskie wobec wyzwań i zagrożeń I połowy XX wieku (w świetle «Szkoły»)", Wychowanie w rodzinie XIV/2 (2016): 209-230; Agnieszka Wałęga, „Dziedzictwo wielkopolskiej myśli pedagogicznej w przekazie «Szkoły» (1868-1939)”, w: Wielkopolska i Wielkopolanie w dziejach polskiej edukacji, red. Edyta Głowacka-Sobiech, Katarzyna Kabacińska-Łuczak (Poznań: Uniwersytet Adama Mickiewicza, 2017), 475-489. 


\section{Relacje Kościoła i szkoły w świetle nowych przepisów prawnych}

Wraz z powołaniem w 1867 roku w Galicji Rady Szkolnej Krajowej ${ }^{13}$ i rozpoczęciem epoki tak zwanej autonomii pojawiły się głosy o zagrożeniu, jakie nowe przepisy i rozporządzenia mogą stanowić dla dotychczasowej pozycji Kościoła jako opiekuna szkół. Wpływ tych głosów, niezwykle szkodliwych dla rozwoju szkolnictwa oraz niepokojących ludność, starano się niwelować, wyjaśniając założenia wprowadzanych wówczas ustaw. Swój udział w tego typu działaniach miała także Szkoła. Już w pierwszym zeszycie tego pisma ukazał się artykuł pod wymownym tytułem „Uwagi nad obawami tych, co w nowej ustawie w Radzie szkolnej krajowej niekorzyść dla kościoła chcą upatrywać"14. Jego autorem był Andrzej Oskard, ówczesny inspektor krajowy szkół średnich w Galicji Zachodniej, tłumacz mów Demostenesa, wieloletni nauczyciel gimnazjalny języka greckiego, historii oraz propedeutyki filozofii. Ten doświadczony działacz oświatowy i pedagog, który w kolejnych latach był między innymi inspektorem szkół całej Galicji oraz dyrektorem słynnego Gimnazjum Franciszka Józefa we Lwowie ${ }^{15}$, w swoim artykule przytoczył dwa główne zarzuty przeciwników wprowadzanych wówczas zmian. Pierwszy z nich dotyczył pozbawienia Kościoła kontroli nad szkołami, drugi miał stanowić bezpośredni skutek tych działań i przewidywał całkowite zerwanie łączności Kościoła z procesami kształcenia i wychowania, co wiązać się miało ściśle z upadkiem moralności i religijności uczniów.

Oskard rozpoczął swój wywód od stwierdzenia, że szkoła zawsze powinna służyć rodzinie, Kościołowi i państwu jednocześnie ${ }^{16}$. Przypomniał, że oświata w Austrii i na terenie Galicji podlegała już wcześniej różnorakim

13 Szerzej na ten temat m.in. Renata Dutkowa, Polityka szkolna w Galicji między autonomią a centralizmem (1861-1875) (Kraków: Uniwersytet Jagielloński, 1995).

${ }^{14}$ A. O. (Andrzej Oskard), „Uwagi nad obawami tych, co w nowej ustawie w Radzie szkolnej krajowej niekorzyść dla kościoła chcą upatrywać”, Szkoła I/1 (1868): 10-18.

15 Tadeusz Ochenduszko, „Leksykon nauczycieli i wychowanków I Gimnazjum i Liceum w Rzeszowie urodzonych pomiędzy XVII wiekiem a 1945 rokiem” (2015), https://www.1lo. rzeszow.pl/index.php?option=com_content\&view=article\&id=731\&Itemid=1694 (dostęp: 3.11.2017).

${ }^{16}$ Nawiązywał tu ewidentnie do myśli Józefa Dietla wyrażonej m.in. w jego pracy O reformie szkól krajowych. Na ten temat szerzej m.in. Agnieszka Wałęga, „Przywrócić polską oświatę. Zasługi Józefa Dietla w dziele repolonizacji szkolnictwa”, w: Przełomy edukacyjne. 
przeobrażeniom, którym Kościół nigdy nie był przeciwny, co nasuwa wniosek o jego akceptacji dla reform w tym zakresie. Głosów protestów nie odnotowano także obecnie, zapewne dlatego, że nowe zasady funkcjonowania szkół uchwalili posłowie katoliccy, a w ustawach zachowano prerogatywy biskupów dotyczące wpływu na zatrudnianie nauczycieli religii czy dobór książek obowiązujących przy jej nauczaniu. Oskard przypomniał także, że w skład Rady Szkolnej Krajowej wchodzić miało każdorazowo dwóch duchownych, a w zakresie kształcenia religijnego dzieci i młodzieży zachowano dotychczasowe rozporządzenia. Osobom zaniepokojonym zmianami wyjaśniał, że:

Bezpośredni wpływ miejscowego duszpasterza na szkołę nie ustał, ustało tylko jego wyłączne, świeckie zwierzchnictwo nad nauczycielami szkoły ludowej. Jednak nauczyciel z dwóch względów będzie zawsze podporządkowany miejscowemu proboszczowi: raz, że jako parafianin wspólne mieć będzie ze wszystkimi wiernymi obowiązki dla swego duszpasterza, a powtóre, że miejscowemu proboszczowi, jako członkowi rady szkolnej miejscowej, chociaż nie wyłączny, ale zawsze pewny wpływ w nadzorze i kierownictwie szkoły przysłużać będzie ${ }^{17}$.

W jego ocenie szkoła nie utraci charakteru katolickiego dopóty, dopóki będzie miało w niej miejsce nauczanie religii i zasad moralności. Odwołując się do obaw dotyczących utraty przez proboszczów uprzywilejowanej pozycji opiekunów szkół i związanego z tym szacunku, wyraźnie zaznaczał, że i dotychczas nie w każdym przypadku duchowni byli nim obdarzani. Jeżeli reprezentant Kościoła otaczał szkołę opieką, dbał o jej rozwój, często ją wizytował, z oddaniem nauczał religii i troszczył się o morale nauczycieli, to ludność ceniła i szanowała jego zaangażowanie. Zdarzały się jednak i takie przypadki, gdy zwierzchność ta ograniczała się niestety jedynie do autorytarnego nadzoru i oczekiwań względem „czołobitności” nauczycieli, a wówczas o szacunek było niezmiernie trudno. Andrzej Oskard zaznaczał, że wychowanie religijne nie odbywa się wyłącznie na terenie szkoły, jej podstawy kształtują przecież rodzice i ogólna atmosfera domu rodzinnego. Uczeń trafia do placówki edukacyjnej z pewnym bagażem postaw i przekonań religijno-

Dziedzictwo polskiej teorii i praktyki, red. Władysława Szulakiewicz (Toruń: Adam Marszałek, 2011), 94-110; Falkowska, Myśl, 277-279.

17 Oskard, „Uwagi nad obawami”, 13. 
-moralnych, które nauczyciele mogą jedynie umacniać. Na linii szkoła-dom powinna panować $\mathrm{w}$ tym zakresie zgodność przekonań i postaw ${ }^{18}$. Ważną rolę przypisywał oczywiście postawie samego nauczyciela, którego miała cechować „czystość charakteru i bogobojność”19. Tylko taki wychowawca zapewniał właściwy przebieg wychowania religijnego w szkole:

Jakimże sposobem wychowawca katolicki, który wierzy, że istota ludzka do dwóch światów należy, że cel człowieka jest jeden ziemski, drugi nadziemski, mógłby pomyśleć o wykluczeniu kościoła od współudziału w sprawie wychowania? Czemżeby się wtenczas różniło wychowanie od hodowania i tresowania zwierząt, gdybyśmy spuścili z oka wyższy cel ten życia naszego, który wskazał Chrystus? $?^{20}$

By uspokoić dalsze obawy w tym zakresie, w kolejnym tomie pisma przedrukowano Ustawę z dnia 25 maja 1868 roku, „mocą której wydaje się zasadnicze ustanowienia względem stosunku szkoły do kościoła" ${ }^{21}$. Powracano też do pytania, jak w nowych realiach powinny układać się relacje nauczycieli i proboszczów. Zalecano, by nawiązywali oni wzajemną współpracę, a duchownym radzono unikać protekcjonalnego traktowania nauczycieli ze względu na ich niższy poziom wykształcenia ${ }^{22}$. Pedagodzy otrzymywali też porady na temat: jak zachować się w konkretnych przypadkach konfliktu interesów z lokalnym duszpasterzem. Doradzano im wówczas częściową uległość i autentyczną skromność, połączoną jednak z poczuciem własnej godności osobistej. Podkreślano, że autonomia i powołanie RSK zmieniły wcześniejszą, zupełną zależność nauczycieli ludowych od proboszczów ${ }^{23}$.

Według przepisów ustawy o szkołach ludowych z 14 maja 1869 roku „obowiązek nauczania religii w szkołach ciąży na odnośnych kościołach i stowarzyszeniach" ${ }^{24}$. Religii nauczać miały osoby duchowne - katecheci

18 Na ten temat szerzej: Wałęga, „O zadaniach”, 137-158.

19 Oskard, „Uwagi nad obawami”, 16.

20 Tamże, 15.

${ }^{21}$ Szkoła II/7 (1868): 61-62.

${ }^{22}$ Ks. Wojciech z Zaleszan, „Urywki pedagogiczne - II. Nauczyciel w stosunku do księdza”, Szkoła 7 (1869): 97-99.

${ }^{23}$ Jan Nepomucen Wasung, ,Stosunek nauczycieli ludowych do miejscowych duszpasterzy”, Szkoła 2 (1889): 244-246; Maria Borucka, „Jak ma postępować nauczyciel wobec proboszcza, dworu i gminy aby pozyskać dla siebie miłość i szacunek a dla szkoły ich współdziałanie?", Szkoła 21 (1890): 237-240.

${ }^{24}$ Romuald Starkel, „W sprawie katechetów”, Szkoła 42 (1886): 330. 
lub „należycie ordynowani świeccy”. W przypadku gdy brakowało katechetów duchownych, RSK zwracała się do okręgowej rady szkolnej o wskazanie kandydatów świeckich. Według projektu ustawy o katechetach i nauczycielach religii w szkołach ludowych publicznych byli oni zobowiązani do zrealizowania minimum 17, a maksymalnie 25 godzin tygodniowo w ramach stałych poborów. Krajowa władza szkolna mogła obniżyć ten przydział, o ile prowadzono dodatkowe nabożeństwa czy inne ćwiczenia religijne dla młodzieży. O mianowaniu katechetów i nauczycieli religii decydowała krajowa władza szkolna, po zasięgnięciu opinii okręgowych władz szkolnych oraz „wyznaniowej władzy zwierzchniej”25.

W praktyce chętnych do nauczania religii w szkołach ludowych wśród duchownych często brakowało. Różne były tego przyczyny - od przeciążenia pracą duszpasterską ${ }^{26}$, poprzez problemy $\mathrm{z}$ wynagrodzeniem ${ }^{27}$, po niechęć do pracy pedagogicznej. Ten ostatni powód otwarcie przedstawiali sami duchowni: „Nauczycielstwo bowiem jako zawód twardy i niewdzięczny młodzi duchowni prędko opuszczają, i porzucając szkoły ludowe przy pierwszej sposobności przenoszą się na korzystniejsze posady, lub sprawują te funkcje zastępczo obok innych obowiązków"28.

\section{Praktyki religijne uczniów i nauczycieli}

„Do pierwszych zadań szkoły należy prowadzić uczniów do poznania i wykonywania wszystkich obowiązków, które każdy chrześcijanin-kato-

25 „Projekt ustawy o katechetach i nauczycielach religii w szkołach ludowych”, Szkoła 40 (1888): 369-370.

${ }^{26}$ Przykładowo w jednym z artykułów przywołano następujące dane obrazujące sytuację Tarnowa. Tamtejsi księża mieli pod opieką 18 tys. parafian i liczne klasy w szkołach żeńskich i przedmiejskich, gdzie realizowali katechezę. Efektem tego przeciążenia był brak katechety w szkole wydziałowej męskiej, o czym z oburzeniem informowała prasa: Kurier Lwowski czy Reforma. Opinię publiczną ta sprawa zbulwersowała szczególnie ze względu na fakt, że uczniowie Izraelici mieli osobnego nauczyciela religii. Patrz: Starkel, „W sprawie”, 329.

27 Początkowo duchowni często wykonywali tę pracę za symboliczne wynagrodzenie, wypłacane im jednorazowo i wyrównawczo, tzw. remunerację. Dopiero w latach 80. XIX wieku podjęto kroki, by wynagradzać katechetów tak jak nauczycieli. Patrz: Starkel, „W sprawie”, 330: „Bądź co bądź trudno żądać za darmo tak ciężkiej pracy, jak nauczycielska, nawet od ludzi najbardziej do poświęceń skorych: daremszczyzna taka zniechęca i przyczynia się tylko do zaostrzenia stosunków".

${ }^{28}$ Martyński, ,Jeszcze uwagi nad Katechizmem dla szkół ludowych”, Szkoła 50 (1874): 473. 
lik znać i wykonywać powinien"29. Taką opinię wyraził na łamach pisma w 1884 roku Bolesław Baranowski, inspektor szkolny na powiat lwowski i miasto Lwów, aktywny działacz Towarzystwa Pedagogicznego i redaktor Szkoły, wkrótce krajowy inspektor szkolny szkół ludowych i seminariów nauczycielskich a tym samym członek RSK ${ }^{30}$. Postulował on wówczas, by wprowadzić jednolite dla wszystkich szkół galicyjskich zasady regulujące obowiązkowe praktyki religijne uczniów i nauczycieli. Sformułował też własne propozycje w tym zakresie. W wersji minimalistycznej, gdy w danej miejscowości pracował tylko jeden ksiądz, miały one obejmować uroczyste nabożeństwa z okazji rozpoczęcia i zakończenia roku szkolnego ze śpiewem Veni Creator i Te Deum, uczestnictwo we mszy w dni świąteczne (takie jak m.in. Środa Popielcowa czy dzień imienin cesarza 4 października) oraz spowiedź wielkanocną. Katalog tych obowiązków ulegał znacznemu rozszerzeniu, gdy na parafii przebywało dwóch lub więcej duchownych. Wówczas uczniowie w okresie jesiennym (wrzesień i październik) oraz letnim (maj i czerwiec) mieli obowiązek codziennego wysłuchiwania mszy, a w pozostałych miesiącach uczestnictwa w nabożeństwach niedzielnych i świątecznych. Przy okazji tych ostatnich ważne było informowanie dzieci o genezie utworzenia poszczególnych świąt i ich znaczeniu dla wiernych. Baranowski poszerzył tu także zakres spowiedzi - uczniowie mieli do niej przystępować 2 lub 3 razy w roku.

Redaktor Szkoły podkreślał, że we wszystkich tych praktykach dzieciom powinni towarzyszyć nauczyciele i nauczycielki. Przedstawiał też szczegółowe zasady uczestnictwa uczniów we mszy, procesjach i innych wydarzeniach z uwzględnieniem konieczności zachowania porządku i godności. Postulował jednak, by praktyki religijne nie zaburzały cyklu kształcenia, przykładowo by msze dla szkół odbywały się rano, przed rozpoczęciem lek$\mathrm{cji}^{31}$. Zalecał, by tak prowadzone wychowanie religijne „było nie dla oka, lecz z przekonania i zrozumienia ich pożyteczności i potrzeby nieodzownej

29 Bolesław Baranowski, „Praktyki religijne uczniów”, Szkoła 19 (1884): 149.

${ }^{30}$ Redakcja, „Baranowski Bolesław Adam”, w: Polski Słownik Biograficzny, t. I, red. Władysław Konopczyński (Kraków: Polska Akademia Umiejętności, 1935), 276-277; Andrzej Meissner, „Bolesław Adam Baranowski - przedstawiciel galicyjskiej pedagogiki urzędowej”, w: Galicja i jej dziedzictwo, t. 9: Biografie pedagogiczne, red. Czesław Majorek, Jerzy Potoczny (Rzeszów: Wyższa Szkoła Pedagogiczna, 1997), 81-92.

${ }^{31}$ Na temat tego, jak uczniowie galicyjscy wspominali uczestnictwo swoich nauczycieli w praktykach religijnych i ich postawy religijne, pisze m.in. Grabowska-Pieńkosz, Zapisani, 169-180. 
wykonywane" 32 . Autor ten dostrzegał w praktykach religijnych uczniów także dodatkowy element mogący zachęcić rodziców do posyłania dzieci do szkoły. Podawał tutaj przykład z własnej praktyki zawodowej, gdy jako nauczyciel zadbał o to, by ksiądz i cała klasa uczestniczyli w pogrzebie jednej z uczennic (było to znaczące, ponieważ w przypadku osób mniej zamożnych rzadko wówczas w takich ceremoniach uczestniczył duchowny). Uzyskał dzięki temu ogromną wdzięczność rodziców dziewczynki. Niechętni wcześniej szkole i zapisaniu do niej starszej córki, bezpośrednio po tej podniosłej ceremonii wymusili na nauczycielu natychmiastowe przyjęcie do klasy swojego młodszego dziecka.

Kilka lat później na łamach pisma zamieszczono szczegółowe przepisy dla nauczycieli ludowych dotyczące między innymi wychowania religijnego młodzieży, co ważne, ustalone przez nich samych ${ }^{33}$. Wychowawcy mieli dbać o chrześcijańskie pozdrowienie przy wchodzeniu dzieci do klasy, rozpoczynanie i kończenie lekcji od modlitwy i pieśni religijnych, tak dobranych, by dzieci mogły później aktywnie uczestniczyć we mszy świętej. Do ich zadań należało też wyjaśnienie dzieciom treści modlitw oraz czuwanie nad opanowywaniem pamięciowym tekstu poszczególnych pieśni. Sami mieli stanowić najlepszy wzór dla uczniów, między innymi pokazać jak zachowywać się podczas modlitwy, na początku roku tylko oni ją odmawiali, z czasem przekazywali te zadania dzieciom. Spóźnialscy mieli czekać pod drzwiami klasy aż modlitwa się zakończy - to miało ich uczyć punktualności. Zalecano też, by nauczyciele nawiązywali dobre kontakty z katechetami, wspierali ich i wspólnie omawiali problemy wychowawcze. Jeśli katecheta wyrażał zgodę, wychowawca uczestniczył w jego zajęciach, by w wypadkach losowych mógł go zastąpić podczas katechezy. Przypominano, że pedagodzy powinni wychowawczo wykorzystać praktyki religijne uczniów takie jak modlitwa, udział we mszy czy przystępowanie do sakramentów. To wszystko miało zapewnić skuteczność ich pracy wychowawczej: „Gdzie Bóg weźmie w posiadanie serca młodzieży, tam młodzież będzie na pewno uległą, karną; zasady moralne przyjmą się łatwo, a prowadzenie młodzieży nie natrafi na żadne przeszkody" 34 .

32 Baranowski, „Praktyki”, 151.

33 „Przepisy dla nauczycieli szkół ludowych, pospolitych i wydziałowych, dotyczące wychowania, nauczania oraz prowadzenia młodzieży (uchwalone przez konferencję okręgową nauczycieli okręgu szkolnego przemyskiego w roku 1885 i zatwierdzone przez C.K. Radę Szkolną okręgową w Przemyślu)", Szkoła 15-18 (1887), 114-115, 123-125, 132-133, 139-141.

34 Tamże, 140. 
Atrakcyjnym dla uczniów uzupełnieniem przytoczonych powyżej praktyk były z pewnością jasełka, organizowane często przez nauczycieli przy pomocy księży i organistów:

Nigdzie atoli zwyczaj ten nie znalazł tyle serdecznego przyjęcia, iście religijno-narodowego powabu, jak u nas, w Polsce, szczególniej wtenczas, gdy już pobożna fantazja dorobiła odpowiedni tekst do wątku dramatu, w formie tak prostej i serdecznej, jak prosta i serdeczna była kiedyś pobożność polska. Tekstem tym, to nasze kolędy, pastorałki skrzętnie zebrane tzw. kantyczki, które Mickiewicz nazywa „pierwszym zawiązkiem narodowej pieśni polskiej”. Takim zbiorem poezji narodowo-religijnej żaden podobno naród pochlubić się nie może ${ }^{35}$.

Zwracano uwagę na fakt, że wymagały one dodatkowego zaangażowania ze strony przeciążonych obowiązkami pedagogicznymi wychowawców, którzy niejednokrotnie przeznaczali własne skromne środki materialne w celu uświetnienia występów swoich podopiecznych: „Ale praca to bardzo miła, a obfita w owoce, tak pod względem religijno-moralnym, jak niemniej i pedagogicznym, łatwo bowiem pojąć, że jasełka kształcą potężnie uczucia religijne" ${ }^{\prime 3}$.

\section{Rola nauczyciela w wychowaniu religijnym uczniów}

Religii w szkołach ludowych nauczać mieli przede wszystkim duchowni, nauczycielom świeckim chętnie natomiast powierzano dodatkowy wpływ na wychowanie religijne uczniów ${ }^{37}$. W tym procesie mieli oni odgrywać znaczącą rolę, zaraz po matkach:

Główną jednak zasadą jego (nauczyciela - A.W.) powinno to być, aby takie rzeczy dobierał, którymi życiu ludzkiemu nadać można podstawę moralną, a to

35 Jan Stopczyński, ,Jasełka w szkole”, Szkoła 3 (1889): 27.

36 Tamże, 28.

${ }^{37}$ Udzielano im w tym zakresie nawet szczegółowych wskazówek, jak dbać o moralność i charakter uczniów, m.in. Eugenia Bartonówna, „Moralno-religijne wychowanie młodzieży w szkole ludowej”, Szkoła 1 (1890): 2-4; Józef Jachimowski, „W jaki sposób szkoła działać będzie korzystnie na rozwój charakteru swoich uczniów?", Szkoła 6-7 (1898): 52-53, 61-62; Marian Jakimowski, „Na jakie przeszkody natrafia moralne wychowanie młodzieży szkolnej i jakimi środkami można je usunąć?”, Szkoła 23-24 (1899): 217-219, 231-233. 
stanie się wtedy, jeżeli w wyjaśnianiu tej lub owej rzeczy nie tylko polegać będzie na podniesieniu jej wartości umiejętnej, ale oraz przedstawi ją ze stanowiska etycznego; czyli po prostu jeżeli taki wybór zrobi, którym by i rozum kształcić i czucie uszlachetnić można ${ }^{38}$.

Autor tych zaleceń, znany galicyjski pedagog i publicysta, nauczyciel gimnazjalny, a wkrótce redaktor Szkoły i okręgowy inspektor lwowskich szkół ludowych, Stanisław Sobieski ${ }^{39}$, zalecał też, by nauczyciele starali się zachęcać całe rodziny do uczestnictwa w zajęciach szkółki niedzielnej. Niekiedy pisano nawet o nauczycielu, że to swoisty obraz „boskiego Mistrza” - ta fraza nie dziwi, gdy uwzględnimy fakt, że autor tego ideału pedeutologicznego Józef Chmielewski, profesor seminarium nauczycielskiego w Tarnowie i krajowy inspektor szkolny, wzorował swój tekst na artykule z Wiadomości kościelnych dotyczącym walorów dobrego katechety ${ }^{40}$.

Nauczyciele powinni zatem dbać o dobre przykłady, w tym zwłaszcza wzór własnego życia ${ }^{41}$, i dążyć do zaszczepiania w wychowankach głębokich przeżyć religijnych: „Przykłady etyczne w praktyce, biblii i ewangelii i w książce szkolnej utworzą piękną całość, którą wpływać należy na wychowanie religijne młodzieży" ${ }^{\prime 2}$. Taką opinię wyraził nauczyciel i działacz oświatowy Szczęsny Parasiewicz ${ }^{43}$ w 1884 roku, deklarując:

Wychowanie bowiem bez rozwijania uczuć religijnych i etycznych, nie może zawierać w sobie pierwiastków i zasadniczych danych, przyszłej w życiu szczęśliwości człowieka; wychowanie takie to budowa gmachu olbrzymiego

38 Stanisław Sobieski, „Czego mamy obecnie żądać po nauczycielu szkół ludowych”, Szkoła I/4 (1868): 231.

39 Redakcja, „Sobieski Stanisław”, w: Polski Stownik Biograficzny, t. XXIX, red. Henryk Markiewicz (Warszawa-Kraków: Instytut Historii Polskiej Akademii Nauk, 1999-2000), 510-511.

${ }^{40}$ Józef Chmielewski, „Jakie są przymioty dobrego nauczyciela”, Szkoła 15 (1876): 137-139.

${ }^{41}$ Religijność i moralność zawsze wymieniano wśród „Kardynalnych przymiotów nauczyciela”. Por. m.in. Edward Petryka, „Jakie przymioty powinien posiadać dobry nauczyciel? (odczytano na walnym zgromadzeniu pedagogicznym w Chrzanowie dnia 12 kwietnia 1870 r.)", Szkoła 18-19 (1870): 273-278, 289-293; Chmielewski, ,Jakie są przymioty”, 137-139; Józef Dobrowolski, „Kilka słów o indywidualności nauczyciela”, Szkoła 9 (1889): 83-84.

42 Szczęsny Parasiewicz, „Nie ma teraz dzieci”, Szkoła 46 (1884): 379.

43 Marian Tyrowicz, „Parasiewicz Szczęsny”, w: Polski Słownik Biograficzny, t. XXV, red. Emmanuel Rostworowski (Wrocław: Ossolineum, 1980), 194. 
bez fundamentów, którego ściany lada powiew wichru wstrząśnie i tę mniemaną wielkość w drobny pył zamieni ${ }^{44}$.

Parasiewicz przytaczał przykłady szkół francuskich, w których rodzice domagali się laicyzacji edukacji i zwolnienia dzieci z praktyk religijnych. Zauważał, że w Galicji „na szczęście” nie było podobnych tendencji, a wychowanie na tamtych terenach opierało się na silnych podstawach tradycji i religii.

Podobne opinie spotykamy i w innych tekstach zamieszczonych na łamach tego periodyku. W 1891 roku w artykule poświęconym kształceniu uczuć religijnych zdecydowanie zanegowano takie trendy jako zagrażające porządkowi społecznemu i mające swoje źródła w ,przewrotności i głupocie". Uczucia religijne określono mianem niezbędnych dla człowieka, stanowiących podstawę i podporę jego postawy moralnej oraz ładu społecznego: „Twierdzenie, jakoby wywoływano je w sposób sztuczny i nienaturalny, za pomocą przymusu, jest pozbawione wszelkich podstaw i dowodzi co najmniej niedokładnego rozpatrzenia się w rzeczy" ${ }^{45}$.

Uczucia religijne uznawano za naturalne dla człowieka, to z nimi przychodził na świat, następnie dom rodzinny, rodzice powinni troszczyć się o ich rozwój. Podkreślano, że religijność kształtuje się głównie poprzez uczestnictwo w życiu domowym i publicznym, jednak i szkole przyznawano w tym zakresie ważne zadania. To szkoła posiadała odpowiednie środki wychowawcze do kształtowania uczuć religijnych. Zaliczano do nich oczywiście osobisty przykład nauczyciela, który

posiada głęboką wiarę, niekłamaną pobożność, skromność i pokorę chrześcijańską, kto tego nie posiada, kto kłamstwem i obłudą chce pokryć swą moralną nędzę, ten z pewnością nie wychowa religijnych ludzi; pokolenie, pod wpływem takiego przykładu wyrosłe, będzie pokoleniem kłamców, obłudnych świętoszków ${ }^{46}$.

44 Parasiewicz, „Nie ma teraz”, 379.

45 Antoni Adamus, „Kształcenie uczuć religijnych”, Szkoła 41 (1891): 485.

46 Julian Maciołowski, „O kształceniu uczuć religijnych”, Szkoła 1 (1893): 2-4. Swoje uwagi względem tego tekstu, a raczej rodzaj teologicznego uzupełnienia prezentowanych tam treści zamieścił w kolejnym numerze znany galicyjski katecheta Walenty Gadowski (zob. Szkoła 2 [1893]: 17-19). 
Wśród innych środków wymieniono dyscyplinę szkolną, ćwiczenia religijne uczniów i nauczycieli oraz sam proces nauczania, zwłaszcza w zakresie historii i przyrody. W kontekście nauk przyrodniczych często odwoływano się do przykładu Izaaka Newtona, który za każdym razem, gdy odwoływał się do Boga, z szacunku dla niego zdejmował z głowy czapkę.

Religijny charakter szkoły ludowej nie tylko zgadza się z fundamentalnymi zasadami pedagogii, ale nadto najdzielniejszym jest środkiem utrzymania młodzieży szkolnej w karności, bo cóż może być potężniejszym hamulcem dziecięcej pustoty i swawoli, jeśli nie myśl o wszystkowiedzącym Bogu ${ }^{47}$

- tak pisała Helena Udzielowa, późniejsza współzałożycielka Towarzystwa Muzeum Etnograficznego w Krakowie ${ }^{48}$. Nauczyciel kształtuje uczucia religijno-moralne dzieci poprzez uświadamianie im obowiązków wobec rodziców i samych siebie, poszanowanie dla cudzej własności, wdrażanie do zachowywania przyzwoitości i porządku oraz kształtowanie współczucia i miłosierdzia wobec innych. Codziennie powinien stwarzać dzieciom szansę na wykonywanie dobrych uczynków oraz wpajać im podstawy właściwych zachowań, odwołując się na przykład do rozwiązywania ich wzajemnych konfliktów: „Kierowanie się we wszystkich czynnościach woli zasadami moralnymi, podporządkowanymi pod najwyższą zasadę, jaką jest wola Boża, jest ideałem, do którego zdąża wychowanie religijno-moralne, jest prawdziwie moralnym charakterem"49.

Podkreślano różnice pomiędzy nauką religii, budzącą pojęcia i uczucia religijne, a wychowaniem religijnym, które uznawano za najważniejszy element pracy pedagogicznej w szkole ludowej: „Prawdziwa religia musi pojęcia i uczucia religijne łączyć koniecznie z życiem moralno-religijnym"50. Zasłużony galicyjski pedagog, jeden z pierwszych redaktorów Szkoty, autor licznych prac pedagogicznych, Bronisław Trzaskowski ${ }^{51}$, wskazując na rolę

${ }^{47}$ Helena Udzielowa, ,Jakimi środkami i w jaki sposób powinna szkoła ludowa kształcić w młodzieży uczucia moralno-religijne”, Szkoła 47 (1886): 369.

48 VIII Sprawozdanie Wydziału Towarzystwa Muzeum Etnograficznego w Krakowie za rok 1918 i 1919 (Kraków: Towarzystwo Muzeum Etnograficznego, 1920), 11.

49 Udzielowa, ,Jakimi środkami”, 369.

${ }^{50}$ Bronisław Trzaskowski, ,Kilka uwag w sprawie religijnego wychowania młodzieży szkolnej”, Szkoła 1 (1892): 11.

${ }^{51}$ Andrzej Meissner, „Bronisław Trzaskowski (1824-1906)”, w: Studia z dziejów oświaty XVIII-XX wieku, red. Mirosława Chamcówna (Wrocław: Uniwersytet Wrocławski, 1993), 
domu rodzinnego, a przede wszystkim matki w kształtowaniu pierwszych doświadczeń religijnych dziecka, przytaczał przykład Gertrudy z prac pedagogicznych Jana Henryka Pestalozziego ${ }^{52}$ (jako inny wzór podawano m.in. św. Monikę, matkę św. Augustyna $)^{53}$. Zwracał także uwagę na postawę samych nauczycieli, którzy powinni być dla swoich uczniów wzorem etycznym nie tylko w szkole, ale i poza nią. Absolutnie wykluczał możliwość kształtowania w uczniach postaw nietolerancji wobec innych wyznań czy próby wywyższania jednego wyznania kosztem pozostałych, co w wielowyznaniowym wówczas społeczeństwie Galicji miało ogromne znaczenie.

\section{Wskazówki metodyczne i ocena katechizmów}

Zdaniem współpracowników pisma Szkoła, edukację religijną należało rozpoczynać na wczesnym etapie rozwoju dziecka (negowano wyraźnie zalecenia, jakie w tym zakresie dawał m.in. Jan Jakub Rousseau ${ }^{54}$ ), od najmłodszych lat przyzwyczajać je do praktyk religijnych w gronie rodzinnym, aż staną się one dla niego naturalne. Jednocześnie polecano wprowadzanie elementów historii biblijnej w formie krótkich opowiadań. Postulowano, by do celów tej edukacji wykorzystać muzykę, śpiew, ikonografię, a nawet poezję. Dziecko w wyniku tak prowadzonej nauki i wychowania miało uczyć się postrzegać Boga jako stwórcę całego świata. Zalecano, by nauczyciele, wychowawcy i rodzice unikali w wychowaniu religijnym wszelkiego fanatyzmu, przesady, przymusu czy gróźb. Powinni oni natomiast dbać o kształtowanie w dzieciach ,głosu sumienia”, czyli swoistego związku religii z moralnością: „Świadomość religijna jest najlepszą przewodniczką życia, ona bowiem chroni od pyszałkostwa w powodzeniu, podnosi w nieszczęściu, zapala i pociąga umysł do ideałów, uśmierza wzburzone namiętności i pobudza wolę do działania w kierunku przez się wytkniętym"55.

67-79; Andrzej Meissner, Spór o duszę polskiego nauczyciela. Społeczeństwo galicyjskie wobec problemów ksztatcenia nauczycieli (Rzeszów: Wyższa Szkoła Pedagogiczna, 1999).

${ }_{52} \mathrm{Na}$ ten temat szerzej m.in. Ryszard Wroczyński, „Wstęp”, w: Jan Henryk Pestalozzi, Pisma pedagogiczne, oprac. Ryszard Wroczyński (Wrocław: 1972), XIV-XVI.

53 Taki przykład podawał w swoim artykule Julian Maciołowski.

${ }^{54} \mathrm{Na}$ ten temat szerzej m.in. Monika Hajkowska, „Koncepcja wychowania dziewcząt i chłopców Jana Jakuba Rousseau i jej recepcja w literaturze pedagogicznej XX w.”, Lubelski Rocznik Pedagogiczny XX (2000): 196-197.

55 Adamus, „Kształcenie uczuć”, 485. 
Jeden z czołowych reprezentantów koncepcji wychowania narodowego Bronisław Trzaskowski na łamach Szkoły negował koncepcje rozpoczynania nauki religii w pierwszych klasach szkoły ludowej od pamięciowej nauki katechizmu czy historii biblijnych. Na tym etapie zalecal proste powiastki dostosowane do dotychczasowych przeżyć i doświadczeń dziecka. Później stopniowo proponował wzbogacić je elementami z historii biblijnej, z jasnym przesłaniem dla ucznia. Także on popierał pomysł, by metodykę religii uzupełnić wierszykami i piosenkami, albowiem „W ogólności nie należy przy nauce religii pomijać poetycznej strony umysłu ludzkiego, która jak wiadomo, gra niepoślednią rolę w religijnym rozwoju człowieka" ${ }^{56}$. Dopiero ostatnie lata nauki w szkole ludowej to czas odpowiedni na syntezę elementów historycznych, dogmatycznych i etycznych edukacji religijnej: „Taka całość, jako z własnej wiedzy uczniów wysnuta i na ich własnym doświadczeniu oparta, może dopiero stać się ich religijnym przekonaniem i przyczynić się skutecznie do ich religijnego wykształcenia" ${ }^{57}$.

Podobną opinię wyraził w latach 70. XIX wieku także współpracujący $\mathrm{z}$ pismem reprezentant duchowieństwa ${ }^{58}$. To właśnie w tamtym okresie katechizmy zostały na kartach Szkoły poddane wnikliwej krytyce ${ }^{59}$. Zarzucano im prezentowanie dzieciom zbyt trudnych dla nich treści, niezrozumiałym i dalekim od poprawności językiem, przesyconym licznymi germanizmami. Dla szkół ludowych obowiązywały wówczas dwa katechizmy - tak zwany mały (przeznaczony dla najmłodszych uczniów) i wielki (dla klas starszych) ${ }^{60}$.

56 Trzaskowski, „Kilka uwag”, 13.

57 Tamże.

${ }^{58}$ Martyński, „Jeszcze uwagi”, 473-474.

59 Edward Gabryelski, „Kilka uwag nad katolickimi Katechizmami szkół ludowych”, Szkoła 47 (1874): 442-444; Martyński, „Jeszcze uwagi”, 472-474.

${ }^{60}$ Wśród zatwierdzonych do użytku szkół ludowych katechizmów znalazły się m.in. prace francuskiego jezuickiego teologa, katechety Josepha Deharbe. Jego mały katechizm był m.in. jedynym dopuszczanym dla niższych szkół ludowych z językiem wykładowym ruskim (por. Szkoła 37 (1873): 396; Szkoła 3 (1888): 24), natomiast katechizm większy tego autora zalecono m.in. w latach 80. XIX wieku dla diecezji tarnowskiej, przemyskiej i lwowskiej. Por. Katechizm większy dla szkót ludowych podtug ks. J. Deharba, oprac. Ks. M. Morawski TJ (Lwów: Ossolineum, 1892), 2. Pierwszej adaptacji jego katechizmów na j. polski dokonano w latach 70. XIX w. W kolejnych dekadach lat 80. i 90. XIX wieku ukazało się kilkanaście wydań katechizmu mniejszego i większego tego właśnie autora. Popularne opracowania z zakresu katechezy i dziejów biblijnych dla szkół ludowych przygotowywał także znany galicyjski katecheta Walenty Gadowski. Pełny wykaz obowiązujących w Galicji katechizmów dla szkół 
Katechizm wielki początkowo był oparty na metodzie wykładowej, z czasem zmieniono ją jednak na erotematyczną (pytań i odpowiedzi). Jeden ze współpracowników pisma proponował, by ogłosić konkurs na nowy katechizm dostosowany do możliwości intelektualnych dziecka. Było to zagadnienie niezwykle istotne, albowiem naukę religii postrzegano wówczas jako najlepszy środek wychowawczy dla szkół ludowych.

Artykuł ten zainspirował jednego z galicyjskich duchownych do przesłania Redakcji własnych refleksji na ten temat. Są one tym bardziej cenne, że pochodzą od osoby bezpośrednio zainteresowanej tym problemem. Ksiądz Martyński zgadzał się z negatywną oceną dotychczasowych katechizmów i koniecznością jak najszybszego opracowania nowej pozycji do nauczania religii. Zwracał jednak uwagę na liczne trudności: „,...) napisanie katechizmu, który by był wolny od błędów dogmatycznych i zarazem zakreślił sumiennie moralność, do której katolicy są obowiązani jest niezawodnie zadanie najtrudniejsze w piśmiennictwie treści religijnej”" ${ }^{\text {. Wiele }}$ osób podejmowało takie próby, a źródła ich porażek Martyński upatrywał w braku doświadczenia w pracy katechetycznej z dziećmi i młodzieżą i niezrozumieniu jej specyfiki. Nie pochwalał postawy tych nauczycieli religii, którzy w swojej pracy zupełnie rezygnowali z używania katechizmów i innych pomocy dydaktycznych, i przypominał, że szkoła ludowa ma znaczące obowiązki w zakresie nauki religii: „(...) wielu edukację kończy właśnie w szkołach ludowych, byłoby zatem rzeczą niesumienną, puścić ich w świat nieznających dokładnie tych koniecznych prawd wiary, stanowiących raz na całe życie podstawę religijną i moralną człowieka"62.

Warto także podkreślić, że na łamach Szkoły regularnie zamieszczano informacje na temat książek i podręczników zalecanych przez władze szkol-

ludowych odnaleźć można w publikacji Książi szkolne w szkołach ludowych galicyjskich $i$ innych ziemiach polskich dawniej używane, zebrali i skatalogowali Mieczysław Baranowski i Szczęsny Parasiewicz (Lwów: C.K. Rada Szkolna Miejska Okręgowa, 1898) oraz w Bibliografii dziejów oświaty $i$ wychowania w Galicji 1772-1918, cz. I: Źródła drukowane, red. Andrzej Meissner, Julian Dybiec (Rzeszów: Wydawnictwo Uniwersytetu Rzeszowskiego, 2007), 103-109. Do katechizmów przygotowywano przewodniki metodyczne. Ich popularnym autorem był ks. Józef Krukowski, opublikował m.in. Przewodnik praktyczny do nauczania katechizmu w klasie pierwszej szkół ludowych (Kraków, 1876; wyd. II Kraków, 1883); Przewodnik praktyczny do nauczania katechizmu dzieci III. i IV. klasy szkót ludowych objaśniający katechizm podług ks. Deharbe (Kraków: 1883) - wspomina o nim Szkoła 1 (1884): 6.

${ }^{61}$ Martyński, ,Jeszcze uwagi”, 473.

62 Tamże, 474. 
ne do nauki religii i to zarówno katolickiej, jak i dla wyznania mojżeszowego $^{63}$ czy ewangelików ${ }^{64}$.

\section{Oficjalne stanowisko Redakcji Szkoly w sprawie wychowania religijnego w Galicji}

W 1891 roku Redakcja Szkoły obszernie przedstawiła swoje stanowisko w zakresie wychowania religijnego, odnosząc się do artykułu opublikowanego anonimowo na łamach poznańskiego Przegladu Kościelnego. Jego autor poddał wnikliwej krytyce stan edukacji religijnej w Galicji oraz postawy religijne nauczycieli, a jego opinia została szeroko rozpowszechniona za pomocą osobnych odbitek tego tekstu, które dotarły również do redakcji lwowskiego periodyku. Oburzona Redakcja zarzuciła autorowi brak znajomości stosunków galicyjskich oraz szkalowanie tamtejszych pedagogów i władz szkolnych:

Zarzut powyższy, tak ogólnie wypowiedziany o wychowaniu młodzieży w szkołach naszych, a trafiający cały stan nauczycielski i nasze władze szkolne, musi

${ }^{63} \mathrm{Na}$ łamach Szkoły problemy edukacji religijnej dzieci żydowskich poruszano głównie w kontekście krytyki chederów (zwanych tam chajderami), czyli pokątnych szkółek religijnych uczących j. hebrajskiego, którego znajomość była niezbędna dla judaistycznych praktyk religijnych. Patrz: Glazer, „Stanowisko nauki religii i j. hebrajskiego w szkole czteroklasowej miejskiej na Kazimierzu w Krakowie”, Szkoła 15 (1871): 119-120; Glazer, „Szkoła izraelicka na Kazimierzu w Krakowie”, Szkoła 8 (1871): 59-60; Rafał Brauner, „Jeszcze kilka słów w sprawę arcyważnej (o chajderach galicyjskich)”, Szkoła 17 (1875): 130-133; Neh Landes, „Szkoły żydowskie pokątne (chajdery) wobec ustawy szkolnej z dnia 30 marca 1873”, Szkoła 16 (1875): 121-123. Szerzej na temat chederów i edukacji religijnej Żydów m.in. Joanna Cukras-Stelągowska, „Od chederu do jesziwy w polskiej diasporze...- dwustopniowy system żydowskiego szkolnictwa religijnego i jego współczesne transformacje", Paedagogia Christiana 1/23 (2009): 121-127. W Galicji w 1872 roku wprowadzono religię mojżeszową do szkół publicznych, pod warunkiem że uczęszczało do niej co najmniej 20 uczniów tego wyznania. Od 1879 roku uwzględniano w planach nauki święta żydowskie, a w 1883 zalecono język hebrajski jako nadobowiązkowy. Szerzej na ten temat m.in. Mirosław Łapot, „Nauczycielki religii mojżeszowej w szkołach publicznych w Galicji w latach 1867-1939”, Prace Naukowe Akademii im. Jana Dtugosza w Częstochowie, Seria: Pedagogika XX (2011): 407-418.

${ }^{64}$ Por. Michał Frąckiewicz, Spis przedmiotów zawartych w XXV rocznikach ",Szkoly” (Lwów: Towarzystwo Pedagogiczne, 1894), 281-282. Należy jednak zaznaczyć, że poza krótkimi wzmiankami o tych publikacjach na łamach Szkoły nie poruszano szerzej specyficznych problemów związanych z edukacją religijną ewangelików i grekokatolików. 
my nazwać bez ogródek oszczerstwem. Nie godzi się takich sądów potępienia wydawać o szkołach naszych i o naszem nauczycielstwie, które jest na wskroś religijne i wychowuje dziatwę, jak Pan Bóg przykazał, tj. w duchu religijnym! ${ }^{65}$

W odpowiedzi przywoływano przykład Belgii, w której władze wywodzące się z partii katolickiej umożliwiły znaczną swobodę w decydowaniu przez rodziców o edukacji religijnej ich dzieci. Tymczasem w Galicji nauka religii była obowiązkowa dla każdego dziecka od szkółki froeblowskiej do ukończenia gimnazjum włącznie, a negatywna ocena z tego przedmiotu uniemożliwiała promocję. Władza duchowna miała także zapewniony udział swoich reprezentantów w radach szkolnych. Obalano także zarzuty dotyczące korzystania przez nauczycieli w seminariach $\mathrm{z}$ antyreligijnej literatury pedagogicznej, za jaką autor uważał prace czeskiego pedagoga Gustava Lindnera. Seminarzystom zalecano bowiem dokonany przez znanego pedagoga i działacza oświatowego Zygmunta Sawczyńskiego ${ }^{66}$ przekład dzieł niemieckiego pedagoga i nauczyciela seminarium w Heiligenstadt Lorenza Kellnera, używanych powszechnie $\mathrm{w}$ niemieckich katolickich zakładach kształcenia nauczycieli.

Redakcja podkreślała, że „Ciężką krzywdą, wyrządzoną naszym nauczycielom jest twierdzenie (...) jakoby nauczyciele «nie zalecali religii». I owszem powszechnie żyją religijnie i dają dziatwie przykład religijności. Nasz nauczyciel związany z ludem, żyje z nim i wierzy wiarą ojców jego: to jego patriotyzm" ${ }^{67}$. W jej ocenie nauczycielstwo powszechnie uczestniczyło w praktykach religijnych uczniów, a jeżeli czasami nie przystępowało z nimi do spowiedzi, to wyłącznie ze względów organizacyjnych - gdy spowiadał tylko jeden kapłan, pedagodzy musieli przede wszystkim dbać o bezpieczeństwo i zachowanie podopiecznych.

Na zarzut dotyczący zbyt małego wymiaru godzin lekcji religii $-2 \mathrm{w}$ tygodniu, odpowiadano, że jest on wystarczający, o ile lekcje są dobrze prowadzone, ponadto zaznaczano, że i nauczyciele świeccy przekazują dzieciom treści religijne przy nauce innych przedmiotów, a nawet przy poznawaniu

${ }^{65}$ Redakcja, „Nauka religii w szkołach galicyjskich”, Szkoła 49 (1891): 589.

${ }^{66}$ Elżbieta Głaz, „Zygmunt Sawczyński - pedagog, polityk i działacz oświatowy”, w: Galicja i jej dziedzictwo, t. 9: Biografie pedagogiczne, red. Czesław Majorek, Jerzy Potoczny (Rzeszów: Wyższa Szkoła Pedagogiczna, 1997), 41-58.

${ }^{67}$ Redakcja, ,Nauka religii, 591. 
elementarza. Krytyce planów nauczania i podręczników przeciwstawiono wprowadzone kilka lat wcześniej jednolite programy ${ }^{68}$ i nowy katechizm:

świeccy nauczyciele, którym wypada wyręczać duszpasterza udzielaniem nauki religii są obecnie $\mathrm{w}$ daleko lepszym położeniu gdyż te nowe plany (...) podają cały tok nauki z największą szczegółowością i zawierają mnóstwo cennych wskazówek i metod, tak że nauczyciel wie dokładnie co brać i jak brać ${ }^{69}$.

Redakcja zgadzała się z opinią, że religii powinni uczyć wyłącznie kapłani, a nie świeccy ${ }^{70}$, jednak ze względu na brak odpowiedniej liczby katechetów dopuszczała takie praktyki, pytając retorycznie: czy lepsza byłaby sytuacja pozostawiania dzieci bez żadnej edukacji religijnej? Rolą świeckich było natomiast uczenie religijności i wychowywanie dzieci w duchu religijnym, co - jak stwierdzano - ogół galicyjskich nauczycieli zawsze realizował.

\section{Podsumowanie}

Współpracownicy czasopisma Szkoła regularnie podejmowali na łamach tego pisma problemy dotyczące edukacji religijnej, ze względu na profil pisma w sposób szczególny uwzględniano konteksty dotyczące szkół ludowych. Kwestie religijne wyraźnie wpisywano w całokształt pracy wychowawczej szkół oraz wywierającej na nie znaczny wpływ koncepcji wychowania narodowego. Nie pomijano żadnego z ważnych wątków dyskusji, od celu edukacji religijnej, jej metod i środków, poprzez oficjalne relacje szkoły i Kościoła, po osobiste stosunki nauczycieli ludowych i lokalnych proboszczów. Nie unikano tematów trudnych, takich jak brak katechetów

${ }^{68}$ Zostały one nawet opublikowane na łamach pisma. Patrz: „Plan naukowy dla nauki religii w szkołach ludowych pospolitych I klasowych podzielonych i niepodzielonych", Szkoła 1 (1890): 4-6. Redakcja zamieściła wówczas swój komentarz tej oto treści: „Plan ten, ułożony i wydany przez Najprzew. Konsystorz Biskupi diecezji Przemyskiej, przyjętym został i zaleconym także przez Najprzew. Konsystorz Arcybiskupi diecezji Lwowskiej i Najprzew. Konsystorz Biskupi diecezji Krakowskiej. Ponieważ nauczyciele szkół jednoklasowych dość często, za zezwoleniem władz duchownych, a z polecenia Rady szkolnej okręgowej muszą w zastępstwie udzielać nauki religii, przeto podajemy plan ten do wiadomości czytelników «Szkoły» z uwagą, że w podobnych wypadkach nauczyciele mają zastosować się do tego planu”.

${ }^{69}$ Redakcja, ,Nauka religii, 592.

70 Takie opinie wyrażano już wcześniej m.in. Paulin Święcicki, ,Stanowisko nauczyciela wiejskiego", Szkoła 36 (1870): 561-565. 
wśród duchownych czy konflikty nauczycieli świeckich z duchowieństwem. Czytelnika Szkoły uderza jednolite i wyraźnie sformułowane stanowisko pisma w zakresie wychowania religijnego - zupełnie brak w nim głosów i postaw antyreligijnych, co więcej, już same tego typu tendencje zostają potępione. Na ten ważny temat wypowiadali się czołowi reprezentanci galicyjskiego środowiska pedagogicznego, doświadczeni nauczyciele, działacze oświatowi i autorzy prac, jak choćby Bronisław Trzaskowski, Bolesław Baranowski, Stanisław Sobieski, Romuld Starkel czy Szczęsny Parasiewicz. Nie zabrakło też głosów duchowieństwa, które obok znanego katechety Walentego Gadowskiego, reprezentują ks. Wojciech z Zaleszan czy ks. Martyński. Temat wychowania religijnego podejmowano najczęściej w kontekście nauczyciela i jego obowiązków oraz wpływu szkoły na wychowanie moralno-etyczne uczniów i możliwości kształtowania ich charakterów. Lektura Szkoły świadczy wyraźnie o tym, że nauczyciele doceniali możliwości, jakich w tym zakresie dostarczała im właśnie edukacja religijna.

\section{The Image of Religious Education in Galicia in the Second Half of the 19th Century in the Opinion of the Collaborators of Szkota from Lviv (Summary)}

The second half of the 19th century is the time of significant changes for Polish territories under Austrian rule. The autonomy obtained then allowed the educational system to develop, scientific and teachers' circles to form unions, and the concept of national education to be put into practice. This education clearly appreciated the role of religion in shaping the national identity of Polish people. The aim of the article is to show how religious education was carried out in Galicia at that time at the lowest level of education, that is in community schools. The first Galician educational magazine Szkola, published by teachers and educationalists organised in the Educational Research Association, was assumed as the primary source. The magazine, established in 1868 , was mainly devoted to the problems of community schools, and the dissemination of the idea of national education was evident in its pages. Therefore the references to religious education could not go amiss. The collaborators of the magazine, well-known teachers and educationalists, including clergymen, responded to the problems of the relation between the Church and school, their legal determinants, pupils' and teachers' religious practices, the participation of teachers in religious education, or finally the assessment of catechisms and specific methodological instructions for catechists. Their opinions allow to recreate the image of Galician religious education in the second half of the 19th century. 
Keywords: religious education; community schools in Galicia; educational magazine School; moral education; relation between the Church and school.

\section{Obraz edukacji religijnej w Galicji 2. polowy XIX wieku w opinii współpracowników lwowskiej Szkoly (Streszczenie)}

Druga połowa XIX wieku to czas doniosłych zmian dla ziem polskich znajdujących się pod zaborem austriackim. Uzyskana wówczas autonomia umożliwiła rozwój szkolnictwa, zrzeszanie się środowisk naukowych i nauczycielskich oraz realizację koncepcji wychowania narodowego. Wychowanie to wyraźnie doceniało rolę religii w kształtowaniu tożsamości narodowej Polaków. Celem artykułu jest ukazanie, w jaki sposób realizowano edukację religijną w Galicji tamtego okresu na najniższym szczeblu kształcenia, czyli w szkołach ludowych. Za podstawowe źródło przyjęto pierwsze galicyjskie czasopismo pedagogiczne $S z k o t a$, wydawane przez nauczycieli i działaczy oświatowych zrzeszonych w Towarzystwie Pedagogicznym. To założone w 1868 roku pismo poświęcano przede wszystkim problemom szkół ludowych, a szerzenie idei wychowania narodowego, było na jego łamach wyraźnie widoczne. Nie mogło tam zatem zabraknąć także odwołań do edukacji religijnej. Współpracownicy pisma, znani pedagodzy i działacze oświatowi, w tym także osoby duchowne, podejmowali problemy relacji Kościoła i szkoły, ich uwarunkowań prawnych, praktyk religijnych uczniów i nauczycieli, udziału pedagogów w edukacji religijnej czy wreszcie oceny katechizmów i konkretnych wskazówek metodycznych dla katechetów. Ich opinie pozwalają odtworzyć obraz galicyjskiej edukacji religijnej 2. połowy XIX wieku.

Slowa kluczowe: edukacja religijna; szkoły ludowe w Galicji; czasopismo pedagogiczne Szkoła; wychowanie moralne; relacje Kościoła i szkoły.

\section{Bibliografia}

„Plan naukowy dla nauki religii w szkołach ludowych pospolitych I klasowych podzielonych i niepodzielonych". Szkoła 1 (1890): 4-6.

„Projekt ustawy o katechetach i nauczycielach religii w szkołach ludowych”. Szkoła 40 (1888): 369-370.

„Przepisy dla nauczycieli szkół ludowych, pospolitych i wydziałowych, dotyczące wychowania, nauczania oraz prowadzenia młodzieży (uchwalone przez konferencję okręgową nauczycieli okręgu szkolnego przemyskiego w roku 1885 
i zatwierdzone przez C.K. Radę Szkolną okręgową w Przemyślu)". Szkoła 15-18 (1887): 114-115, 123-125, 132-133, 139-141.

„Ustawa z dnia 25 maja 1868 r. mocą której wydaje się zasadnicze ustanowienia względem stosunku szkoły do kościoła”. Szkoła II/7 (1868): 61-62.

Adamus, Antoni. „Kształcenie uczuć religijnych”. Szkoła 41 (1891): 485-487.

Baranowski, Bolesław Adam. „Sprawozdanie Bolesława Adama Baranowskiego odczytane na posiedzeniu Zjazdu Towarzystwa Pedagogicznego dnia 27 sierpnia 1908 r. pt. Czterdziestolecie Towarzystwa Pedagogicznego”. W: Księga Jubileuszowa Polskiego Towarzystwa Pedagogicznego 1868-1908, 1-23. Lwów: Polskie Towarzystwo Pedagogiczne, 1908.

Baranowski, Bolesław. „Praktyki religijne uczniów”. Szkoła 19 (1884): 149-151.

Bartonówna, Eugenia. „Moralno-religijne wychowanie młodzieży w szkole ludowej”. Szkoła 1 (1890): 2-4.

Bibliografia dziejów oświaty $i$ wychowania w Galicji 1772-1918, cz. I: Źródła drukowane, red. Andrzej Meissner, Julian Dybiec, 103-109. Rzeszów: Wydawnictwo Uniwersytetu Rzeszowskiego, 2007.

Bobrowska-Nowak, Wanda. „Problemy pedagogiczne na łamach «Szkoły» w latach siedemdziesiątych ubiegłego stulecia”. Przegląd Historyczno-Oświatowy 2 (1971): 261-277.

Borucka, Maria. ,Jak ma postępować nauczyciel wobec proboszcza, dworu i gminy aby pozyskać dla siebie miłość i szacunek a dla szkoły ich współdziałanie?”. Szkoła 21 (1890): 237-240.

Brauner, Rafał. „Jeszcze kilka słów w sprawę arcyważnej (o chajderach galicyjskich)". Szkoła 17 (1875): 130-133.

Chmielewski, Józef. „Dwanaście artykułów nauczyciela ludowego”. Szkoła 22 (1886): 170.

Chmielewski, Józef. „Jakie są przymioty dobrego nauczyciela”. Szkoła 15 (1876): 137-139.

Cukras-Stelągowska, Joanna. „,Od chederu do jesziwy w polskiej diasporze... - dwustopniowy system żydowskiego szkolnictwa religijnego i jego współczesne transformacje". Paedagogia Christiana 1/23 (2009): 121-135.

Dobrowolski, Jerzy. „Kilka słów o indywidualności nauczyciela”. Szkoła 9 (1889): 83-84.

Dutkowa, Renata. „Polityka szkolna w Galicji 1866-1890”. W: Galicja i jej dziedzictwo, t. 3: Nauka i oświata, red. Andrzej Meissner, Jerzy Wyrozumski, 137-149. Rzeszów: Wydawnictwo WSP, 1995.

Dutkowa, Renata. Polityka szkolna w Galicji między autonomia a centralizmem (1861-1875). Kraków: Uniwersytet Jagielloński, 1995. 
Falkowska, Joanna. „Pierwiastek religijny w wychowaniu narodowym. Postulaty okresu autonomii galicyjskiej". Paedagogia Christiana 2/30 (2012): 29-45.

Falkowska, Joanna. Myśl wychowania narodowego w Galicji okresu autonomii. Twórcy i idee. Toruń: Adam Marszałek, 2013.

Frąckiewicz, Michał, Spis przedmiotów zawartych w XXV rocznikach „Szkoły”. Lwów: Towarzystwo Pedagogiczne, 1894.

Gabryelski, Edward. „Kilka uwag nad katolickimi Katechizmami szkół ludowych”. Szkota 47 (1874): 442-444.

Gadowski, Walenty. „W sprawie artykułu p. Maciołowskiego”. Szkoła 2 (1893): $17-19$.

Glazer. „Stanowisko nauki religii i j. hebrajskiego w szkole czteroklasowej miejskiej na Kazimierzu w Krakowie”. Szkoła 15 (1871): 119-120.

Glazer. „Szkoła izraelicka na Kazimierzu w Krakowie”. Szkoła 8 (1871): 59-60.

Głaz, Elżbieta. „Zygmunt Sawczyński - pedagog, polityk i działacz oświatowy”. W: Galicja i jej dziedzictwo, t. 9: Biografie pedagogiczne, red. Czesław Majorek, Jerzy Potoczny, 41-58. Rzeszów: Wyższa Szkoła Pedagogiczna, 1997.

Grabowska-Pieńkosz, Dorota. Zapisani w pamięci. Nauczyciele zaboru austriackiego w literaturze pamiętnikarskiej. Toruń: Uniwersytet Mikołaja Kopernika, 2016.

Hajkowska, Monika. „Koncepcja wychowania dziewcząt i chłopców Jana Jakuba Rousseau i jej recepcja w literaturze pedagogicznej XX w.". Lubelski Rocznik Pedagogiczny XX (2000): 189-199.

Hołub, Beata. „Studium historyczno-geograficzne narodowości w Galicji Wschodniej w świetle spisów ludności w latach 1890-1910". Annales Universitatis Mariae Curie-Sktodowska, sectio B: Geographia, Geologia, Mineralogia et Petrographia, LXVIII/2 (2013): 15-40.

Jachimowski, Józef. „W jaki sposób szkoła działać będzie korzystnie na rozwój charakteru swoich uczniów?". Szkoła 6-7 (1898): 52-53, 61-62.

Jakimowski, Marian. „Na jakie przeszkody natrafia moralne wychowanie młodzieży szkolnej i jakimi środkami można je usunąć?”. Szkoła 23-24 (1899): 217-219, 231-233.

Karbowiak, Antoni. Polskie czasopisma pedagogiczne. Warszawa: Kasa im. Mianowskiego, 1912.

Katechizm większy dla szkót ludowych podtug ks. J. Deharba, oprac. Ks. M. Morawski TJ, Lwów: Ossolineum, 1892.

Krukowski, Józef. Przewodnik praktyczny do nauczania katechizmu dzieci III. i IV. klasy szkót ludowych objaśniający katechizm podtug ks. Deharbe. Kraków, 1883. 
Krukowski, Józef. Przewodnik praktyczny do nauczania katechizmu w klasie pierwszej szkół ludowych. Kraków, 1876; wyd. II: Kraków, 1883.

Krupa, Marianna. „Szkoła ludowa w Galicji w latach 1772-1790”. Rozprawy z Dziejów Oświaty 24 (1981): 57-83.

Ks. z Zaleszan, Wojciech. „Urywki pedagogiczne - II. Nauczyciel w stosunku do księdza”. Szkoła 7 (1869): 97-99.

Landes, Neh. „Szkoły żydowskie pokątne (chajdery) wobec ustawy szkolnej z dnia 30 marca 1873". Szkoła 16 (1875): 121-123.

Łapot, Mirosław. „Nauczycielki religii mojżeszowej w szkołach publicznych w Galicji w latach 1867-1939". Prace Naukowe Akademii im. Jana Dlugosza w Częstochowie, Seria: Pedagogika XX (2011): 407-418.

Łuczyńska, Barbara. „Udział Towarzystwa Nauczycieli Szkół Wyższych w integrowaniu nauczycieli szkół średnich Galicji 1884-1909". W: Galicja i jej dziedzictwo, t. 3: Nauka i oświata, red. Andrzej Meissner, Jerzy Wyrozumski, 253-268. Rzeszów: Wydawnictwo WSP, 1995.

Maciołowski, Julian. „O kształceniu uczuć religijnych”. Szkoła 1 (1893): 2-4.

Majorek, Czesław. „Towarzystwo Pedagogiczne i «Szkoła» wobec projektów reform kształcenia nauczycieli ludowych w Galicji z lat 1868-1869". Rocznik Naukowo-Dydaktyczny WSP w Krakowie 43 (1972): 289-300.

Majorek, Czesław. „Urzędowa koncepcja ideału nauczyciela szkoły ludowej w Galicji doby autonomicznej”. Rocznik Komisji Nauk Pedagogicznych X (1970): 207-222.

Martyński. ,Jeszcze uwagi nad Katechizmem dla szkół ludowych”. Szkoła 50 (1874): 472-474.

Meissner, Andrzej. „Bolesław Adam Baranowski - przedstawiciel galicyjskiej pedagogiki urzędowej”. W: Galicja i jej dziedzictwo, t. 9: Biografie pedagogiczne, red. Czesław Majorek, Jerzy Potoczny, 81-92. Rzeszów: Wyższa Szkoła Pedagogiczna, 1997.

Meissner, Andrzej. „Bronisław Trzaskowski (1824-1906)”. W: Studia z dziejów oświaty XVIII-XX wieku, red. Mirosława Chamcówna, 67-79. Wrocław: Uniwersytet Wrocławski, 1993.

Meissner, Andrzej. Spór o duszę polskiego nauczyciela. Społeczeństwo galicyjskie wobec problemów kształcenia nauczycieli. Rzeszów: Wyższa Szkoła Pedagogiczna, 1999.

Ochenduszko, Tadeusz. „Leksykon nauczycieli i wychowanków I Gimnazjum i Liceum w Rzeszowie urodzonych pomiędzy XVII wiekiem a 1945 rokiem”. 2015. https://www.1lo.rzeszow.pl/index.php?option=com_content\&view=article\& id=731\&Itemid=1694 (dostęp: 3.11.2017). 
Oskard, Andrzej. „Uwagi nad obawami tych, co w nowej ustawie w Radzie szkolnej krajowej niekorzyść dla kościoła chcą upatrywać”. Szkoła 1 (1868/I): 10-18.

Parasiewicz, Szczęsny. „Nie ma teraz dzieci”. Szkoła 46 (1884): 379.

Pelczar, Roman. „Miejsce wiejskich szkół elementarnych i ich nauczycieli w życiu społeczności chłopskich w Galicji”. Galicja. Studia i materiały 1 (2015): 114-133.

Petryka, Edward. „Jakie przymioty powinien posiadać dobry nauczyciel? (odczytano na walnym zgromadzeniu pedagogicznym w Chrzanowie dnia 12 kwietnia 1870 r.)". Szkoła 18-19 (1870): 273-278, 289-293.

Redakcja. „Baranowski Bolesław Adam”, W: Polski Stownik Biograficzny, t. I, red. Władysław Konopczyński, 267-277. Kraków: Polska Akademia Umiejętności, 1935.

Redakcja. „Nauka religii w szkołach galicyjskich”. Szkoła 49 (1891): 589-593.

Redakcja. „Sobieski Stanisław”. W: Polski Stownik Biograficzny, t. XXXIX, red. Henryk Markiewicz, 510-511. Warszawa-Kraków: Instytut Historii Polskiej Akademii Nauk, 1999-2000.

Sobieski, Stanisław. „Czego mamy obecnie żądać po nauczycielu szkół ludowych”. Szkoła I/3-4 (1868): 152-157, 231-237.

Starkel, Romuald. „W sprawie katechetów”. Szkoła 42 (1886): 329-330.

Stopczyński, Jan. „Jasełka w szkole”. Szkoła 3 (1889): 27-28.

Stopińska-Pająk, Agnieszka. „Wkład czasopisma «Szkoła» w rozwój myśli pedagogicznej”. W: Galicja i jej dziedzictwo, t. 8: Myśl edukacyjna w Galicji, 1772-1918, red. Czesław Majorek, Andrzej Meissner, 169-179. Rzeszów: Wyższa Szkoła Pedagogiczna, 1997.

Świątek, Adam. „«Poległ wśród boju nauczycielskiego». Wspomnienia pośmiertne na łamach czasopisma «Szkoła» jako źródło do historii nauczycielstwa galicyjskiego". W: Addenda do dziejów oświaty. Z badań nad prasa XIX i początków XX wieku, red. Iwonna Michalska, Grzegorz Michalski, 119-130. Łódź: Uniwersytet Łódzki 2013.

Świątek, Adam. „Problem patriotycznego wychowania ludu na łamach lwowskiej «Szkoły» w czasach autonomii galicyjskiej”. W: Czasopiśmiennictwo XIX i początków XX wieku jako źródto do historii edukacji, red. Iwonna Michalska, Grzegorz Michalski, 169-184. Łódź: Uniwersytet Łódzki, 2010.

Święcicki, Paulin. „Stanowisko nauczyciela wiejskiego”. Szkoła 36 (1870): 561-565 .

Trzaskowski, Bronisław. „Kilka uwag w sprawie religijnego wychowania młodzieży szkolnej”. Szkoła 1 (1892): 11-13.

Tyrowicz, Marian. „Parasiewicz Szczęsny”. W: Polski Stownik Biograficzny, t. XXV, red. Henryk Rostworowski, 194. Wrocław: Ossolineum, 1980. 
Udzielowa, Helena. „Jakimi środkami i w jaki sposób powinna szkoła ludowa kształcić w młodzieży uczucia moralno-religijne”. Szkoła 47-48 (1886): 369371, 378-380.

VIII Sprawozdanie Wydziału Towarzystwa Muzeum Etnograficznego w Krakowie za rok 1918 i 1919. Kraków: Towarzystwo Muzeum Etnograficznego, 1920.

Walewander, Edward. Wychowanie chrześcijańskie w nauczaniu i praktyce Kościoła katolickiego na ziemiach polskich w II połowie XIX wieku. Lublin: Towarzystwo Naukowe KUL, 1996.

Wałęga Agnieszka. „«Szkoła» najstarsze galicyjskie czasopismo pedagogiczne wobec myśli pedagogicznej pozytywizmu warszawskiego". W: W stulecie śmierci Jana Władystawa Dawida, red. Hanna Markiewiczowa, 110-119. Warszawa: Akademia Pedagogiki Specjalnej, 2014.

Wałęga, Agnieszka. "Die deutsche Pädagogik in der Zeitschrift «Szkoła». Ein Beitrag zur Rezeptionsgeschichte im 19. Jahrhundert". Studienreihe der Polnischen Historischen Mission. Leben zwischen und mit den Kulturen. Studien zu Recht, Bildung und Herrschaft in Mitteleuropa 2 (2015): 131-147.

Wałęga, Agnieszka. „«Szkoła» źródłem w badaniach historyczno-pedagogicznych polskich instytucji edukacyjnych doby zaborów". Studia Paedagogica Ignatiana 19/2 (2016): 253-270.

Wałęga, Agnieszka. „«Z zaborów...». Galicyjska «Szkoła» wobec problemów rozwoju oświaty w Królestwie Polskim (1905-1918)”. W: Szkolnictwo, opieka $i$ wychowanie $w$ Królestwie Polskim. Od jego ustanowienia do odzyskania przez Polskę niepodlegtości 1815-1918, red. Hanna Markiewiczowa, Iwona Czarnecka, 80-89. Warszawa: Akademia Pedagogiki Specjalnej, 2016.

Wałęga, Agnieszka. „Dziedzictwo polskiej teorii i praktyki pedagogicznej na kartach «Szkoły»". W: Polskie dziedzictwo pedagogiczne - idee i instytucje, red. Joanna Falkowska, 59-75. Toruń: Uniwersytet Mikołaja Kopernika, 2016.

Wałęga, Agnieszka. „Dziedzictwo wielkopolskiej myśli pedagogicznej w przekazie «Szkoły» (1868-1939)". W: Wielkopolska i Wielkopolanie w dziejach polskiej edukacji, red. Edyta Głowacka-Sobiech, Katarzyna Kabacińska-Łuczak, 475-489. Poznań: Uniwersytet Adama Mickiewicza, 2017.

Wałęga, Agnieszka. „Galicyjska «Szkoła» jako przykład czasopisma pedagogicznego okresu zaborów". Acta Universitatis Nicolai Copernici-Pedagogika XXIX (2013): 9-28.

Wałęga, Agnieszka. „Nauczyciele galicyjscy w świetle «Szkoły»”. W: Badania biograficzne w pedagogice. Studia źródtowe i bibliograficzne, red. Władysława Szulakiewicz, 199-211. Torun: Uniwersytet Mikołaja Kopernika, 2015.

Wałęga, Agnieszka. „O zadaniach wychowawczych rodziny. Koncepcje współpracowników czasopisma «Szkoła»”. Wychowanie w rodzinie X/2 (2014): 137-158. 
Wałęga, Agnieszka. „Przywrócić polską oświatę. Zasługi Józefa Dietla w dziele repolonizacji szkolnictwa”. W: Przelomy edukacyjne. Dziedzictwo polskiej teorii i praktyki, red. Władysława Szulakiewicz, 94-110. Toruń: Adam Marszałek, 2011.

Wałęga, Agnieszka. „Rodziny polskie wobec wyzwań i zagrożeń I połowy XX wieku (w świetle «Szkoły»)". Wychowanie w rodzinie XIV/2 (2016): 209-230.

Wasung, Jan Nepomucen. „Stosunek nauczycieli ludowych do miejscowych duszpasterzy”. Szkoła 2 (1889): 244-246.

Wnęk, Jan. „Problemy polskiego szkolnictwa zaboru pruskiego i rosyjskiego na kartach «Szkoły» 1868-1914”. Biuletyn Historii Wychowania 24 (2008): 23-46.

Wroczyński, Ryszard. „Wstęp”. W: Jan Henryk Pestalozzi, Pisma pedagogiczne, oprac. Ryszard Wroczyński, V-LVII. Wrocław: Ossolineum, 1972.

Zarański, Stanisław. Ocenienie „Szkoły” pisma poświęconego sprawom szkół ludowych i średnich tudzież seminariów nauczycielskich. Kraków: Drukarnia pisma Czas, 1868. 